Advances in Science, Technology \& Innovation

IEREK Interdisciplinary Series for Sustainable Development

Manuel Abrunhosa · António Chambel .

Silvia Peppoloni · Helder I. Chaminé Editors

Advances in Geoethics and

Groundwater Management:

Theory and Practice for a

Sustainable Development

Proceedings of the 1st Congress on Geoethics

and Groundwater Management (GEOETH\&GWM'20),

Porto, Portugal 2020

우 EREEK

Springer 
Manuel Abrunhosa - António Chambel .

Silvia Peppoloni · Helder I. Chaminé

Editors

Advances in Geoethics

and Groundwater

Management: Theory

and Practice for a Sustainable

Development

Proceedings of the 1st Congress

on Geoethics and Groundwater

Management (GEOETH\&GWM'20), Porto,

Portugal 2020

黑 Springer 


\title{
Groundwater Vulnerability Assessment in the Naturtejo UNESCO Global Geopark, Portugal
}

\author{
Teresa Albuquerque, Natália Roque, Joana Rodrigues, \\ Isabel Margarida Antunes, and Catarina Silva
}

\begin{abstract}
Nowadays, groundwater vulnerability assessment has become a useful tool for groundwater contamination prevention. Groundwater vulnerability maps provide useful data to protect groundwater resources and work as a tool for the improvement of changes in agricultural patterns and land use applications. The study area of this research survey is the Naturtejo UNESCO Global Geopark, located in central inland Portugal and corresponding to a mainly rural territory where intensive agricultural practices showed a rising tendency in the last decades. The most used method of vulnerability evaluation is the DRASTIC index. In this survey, a modified DRASTIC method, DRASTICAI, is introduced. A new attribute designated as anthropogenic influence is introduced. Map algebra in a GIS environment allowed the computation of two maps by overlaying the needed attributes. The Vila Velha de Rodão and Idanha-a-Nova municipalities show moderate to high vulnerability and, therefore, in need of monitoring, since intensive agricultural practices are the main economic activity. The algebraic subtraction of DRASTIC and DRASTICAI maps revealed a considerable increase in the risk of contamination, over the surveyed area, namely in Idanha-a-Nova where it is observed risk increase up to 45 points, changing from
\end{abstract}

T. Albuquerque $(\bowtie) \cdot$ N. Roque

CERNAS|QRural/Polytechnic Institute of Castelo Branco, Castelo

Branco, Portugal

e-mail: teresal@ipcb.pt

T. Albuquerque

ICT/University of Évora, Évora, Portugal

J. Rodrigues

Geoparque Naturtejo, Idanha-a-Nova, Portugal

I. M. Antunes

ICT/University of Minho, Braga, Portugal

C. Silva

University of Lisbon/IDL, Lisboa, Portugal moderately vulnerable to highly vulnerable and, therefore, stressing the importance of anthropogenic activities.

\section{Keywords}

Naturtejo Geopark • Groundwater • DRASTIC • DRASTICAI • GIS

\section{Introduction}

Nowadays, groundwater vulnerability assessment has become a useful tool for groundwater contamination prevention. Groundwater vulnerability maps provide useful data to protect groundwater resources and to work as a tool for water management with changes in agricultural patterns and land use applications (Babiker et al. 2005; Albuquerque et al. 2013; Awawdeh et al. 2014; Singh et al. 2015). Several authors acknowledge two different types of groundwater vulnerability, the intrinsic vulnerability and extrinsic or specific vulnerability (Stiger et al. 2006): the first term as a function of hydrogeological factors and the second one defined through the potential anthropogenic influence. The most widely used method of vulnerability analysis is the DRASTIC index (Aller et al. 1987), as it is easy to compute with the minimum data requirement.

The main aim of this study was the evaluation of the groundwater vulnerability to contamination, in the Naturtejo Geopark (Fig. 1), using a modified DRASTIC method in a GIS environment. The modified DRASTIC index (DRASTICAI) was made by assigning a new attribute designated as anthropogenic influence.

\section{Materials and Methods}

The DRASTIC model is constructed using combined spatial datasets on depth to groundwater $(D)$, aquifer recharge $(R)$, aquifer media $(A)$, soil media $(S)$, topography $(T)$, impact of 


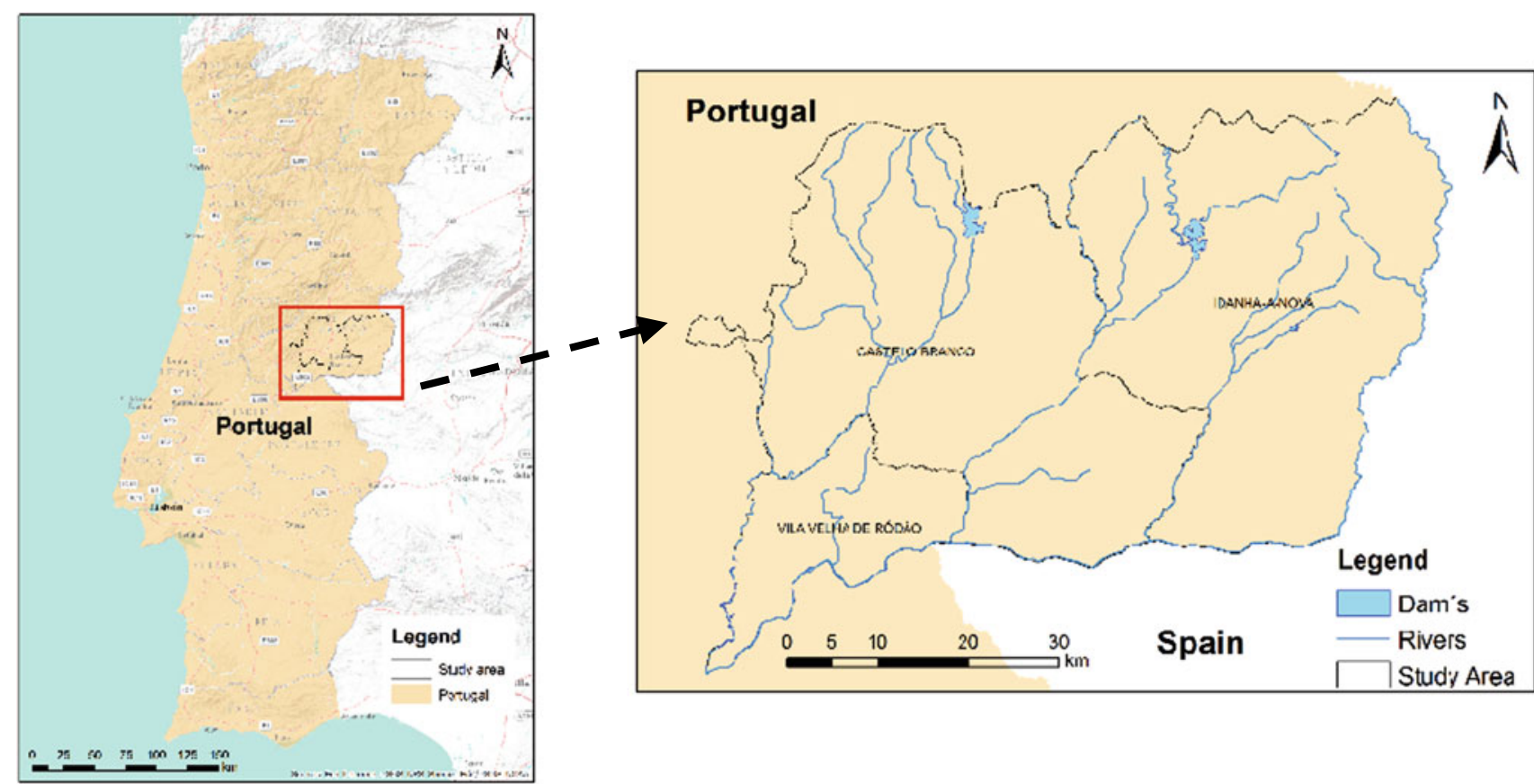

Fig. 1 Study area: Vila Velha de Rodão, Castelo Branco and Idanha-a-Nova municipalities integrating the Naturtejo Geopark

the vadose zone $(I)$ and hydraulic conductivity $(C)$ of the aquifer (Aller et al. 1987). The purpose of the DRASTIC index implies multiplying each factor weight (Table 1) by its category rating (Table 2) as follows:

$$
\begin{aligned}
\text { DRASTIC }= & D_{\mathrm{r}} * D_{\mathrm{w}}+R_{\mathrm{r}} * R_{\mathrm{w}}+A_{\mathrm{r}} * A_{\mathrm{w}}+S_{\mathrm{r}} * S_{\mathrm{w}} \\
& +T_{\mathrm{r}} * T_{\mathrm{w}}+I_{\mathrm{r}} * I_{\mathrm{w}}+C_{\mathrm{r}} * C_{\mathrm{w}}
\end{aligned}
$$

In this study, one extra parameter was added to the DRASTIC model to map the groundwater vulnerability in the study area more accurately, including the anthropogenic influence. This new parameter, anthropogenic influence (AI), was assigned a weight value equal to 5 , and the modified DRASTIC index, DRASTICAI, computed using the following equation:

$$
\begin{aligned}
\text { DRASTICAI }= & D_{\mathrm{r}} * D_{\mathrm{w}}+R_{\mathrm{r}} * R_{\mathrm{w}}+A_{\mathrm{r}} * A_{\mathrm{w}}+S_{\mathrm{r}} * S_{\mathrm{w}} \\
& +T_{\mathrm{r}} * T_{\mathrm{w}}+I_{\mathrm{r}} * I_{\mathrm{w}}+C_{\mathrm{r}} * C_{\mathrm{w}}+A I_{\mathrm{r}} * A I_{\mathrm{w}}
\end{aligned}
$$

where $\boldsymbol{D}$ is depth to groundwater, $\boldsymbol{R}$ is recharge rate (net), $\boldsymbol{A}$ is aquifer media, $\mathbf{S}$ is soil media, $\boldsymbol{T}$ is topography (slope), $\boldsymbol{I}$ is impact of the vadose zone, $\boldsymbol{C}$ is conductivity (hydraulic) of the aquifer, and $\boldsymbol{A I}$ is anthropogenic influence (Table 1):

ArcGIS 10 was used to process the datasets and to create the eight layers, corresponding to the eight considered attributes, and groundwater vulnerability maps by overlaying the available information (Fig. 2).
Table 1 Assigned weights for DRASTIC parameters

\begin{tabular}{l|l}
\hline Parameters & Weight \\
\hline Depth & 5 \\
\hline Recharge & 4 \\
\hline Aquifer media & 3 \\
\hline Soil media & 2 \\
\hline Topography & 1 \\
\hline Impact of vadose zone & 5 \\
\hline Hydraulic conductivity & 3 \\
\hline Anthropogenic influence & $\mathbf{5}$
\end{tabular}

Source Aller et al. (1987) and DRASTICAI 
Table 2 DRASTIC

\begin{tabular}{|c|c|c|}
\hline DRASTIC/DRASTICAI & Range & Rating \\
\hline Depth to groundwater & $<1.5 \mathrm{~m}$ & 10 \\
\hline Recharge rate (net) & $51-102 \mathrm{~mm} /$ year & 3 \\
\hline Aquifer media & $\begin{array}{l}\text { Metamorphic|igneous rock } \\
\text { Stratified arenite and limestone }\end{array}$ & $\begin{array}{l}3 \\
6\end{array}$ \\
\hline Soil media & Thin or absent & 10 \\
\hline Topography (slope) & $\begin{array}{l}<2 \% \\
2-6 \% \\
6-12 \% \\
12-18 \% \\
>18 \%\end{array}$ & $\begin{array}{l}10 \\
9 \\
5 \\
3 \\
1\end{array}$ \\
\hline Impact of the vadose zone & $\begin{array}{l}\text { Shale and clay shale } \\
\text { Stratified arenite and limestone } \\
\text { Metamorphic | Igneous rock }\end{array}$ & $\begin{array}{l}3 \\
6 \\
4\end{array}$ \\
\hline Hydraulic conductivity of the aquifer & $<4.1(\mathrm{~m} / \mathrm{d})$ & 1 \\
\hline Anthropogenic index (Source Singh et al. 2015) & $\begin{array}{l}\text { Built up with high density } \\
\text { Built up with medium density } \\
\text { Built up with low density } \\
\text { Built up with very low density } \\
\text { Agriculture } \\
\text { Forest } \\
\text { Water body } \\
\text { Shrub land } \\
\text { Waste land }\end{array}$ & $\begin{array}{l}9 \\
8 \\
7 \\
5 \\
5 \\
2 \\
1 \\
2 \\
1\end{array}$ \\
\hline
\end{tabular}

Source Aller et al. (1987) and DRATICAI parameters

\section{Results}

For aquifer vulnerability assessment of the study area, seven and eight thematic maps were prepared for the DRASTIC and the DRASTICAI indices computation, respectively (Fig. 3).

The DRASTIC risk map shows two different levels of vulnerability: low and moderate (Fig. 4a). The northern Idanha-a-Nova and Castelo Branco areas show low vulnerability (105-119) as the remaining territory is moderately vulnerable (120-138). However, when analysing the DRASTICAI map, it is possible to identify considerable changes in the spatial patterns of vulnerability (Fig. 4b). Indeed, five levels of growing vulnerability, from low to high, can be acknowledged. Idanha-a-Nova municipality is the most affected by the anthropogenic influence due to intensive farming activities.

\section{Discussion}

Land use parameters can significantly affect hydrogeological parameters. The properties of hydrogeological parameters can be changed by the use of pesticides, the addition of urban and industrial wastes, leakages from septic tanks and waste dumping sites. Land use classification of the study area showed that a major portion of the area is used for agriculture (Fig. 3). Groundwater is more vulnerable to nitrate concentration in agricultural fields. In groundwater systems, nitrate distribution principally depends upon the soil dynamics, recharge rate, groundwater movement and 
Fig. 2 Maps corresponding to the topography and anthropogenic influence
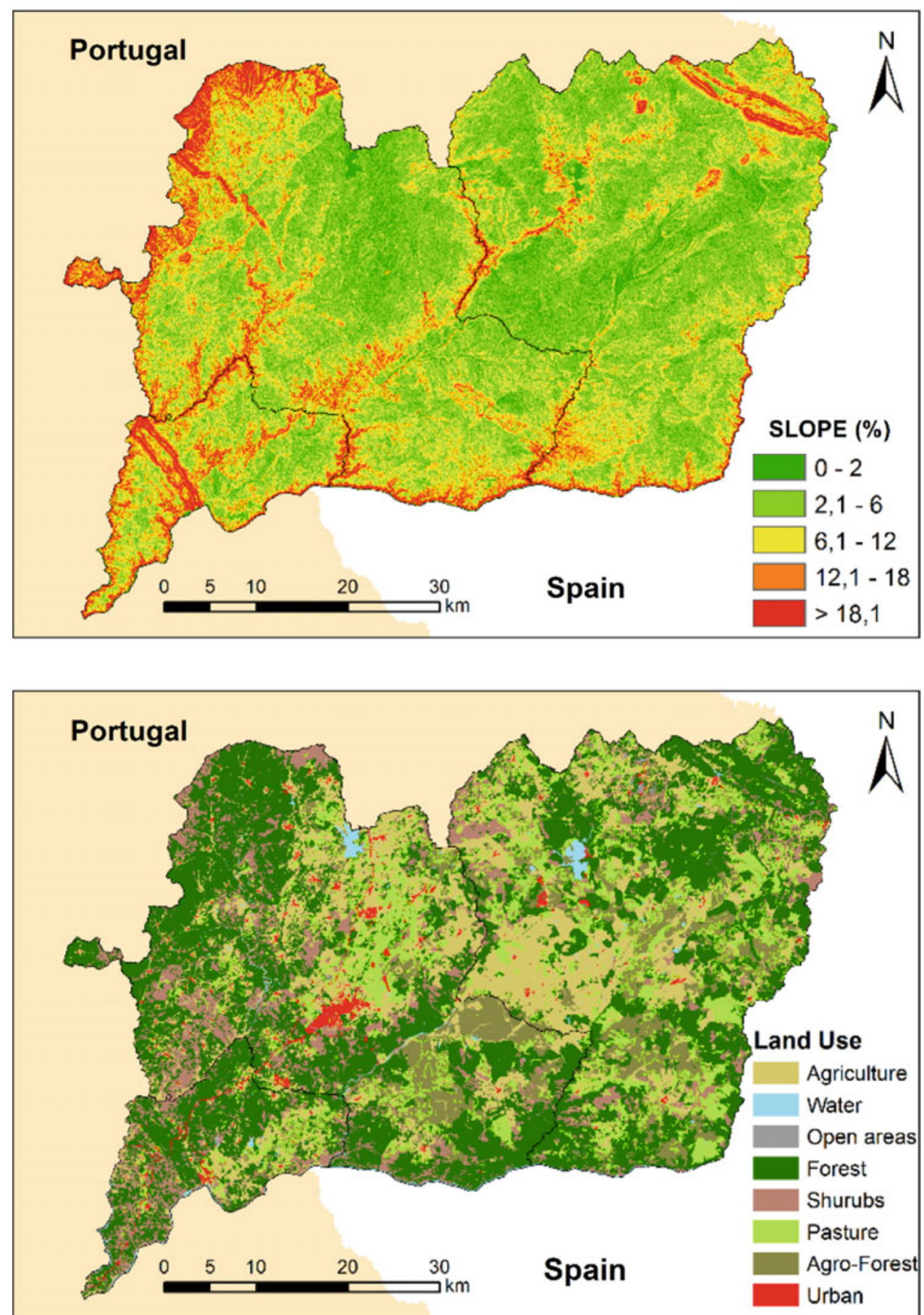

on-ground nitrogen loading (Shirazi et al. 2013). The study area is significantly influenced by agricultural activities.

The algebraic subtraction between the DRASTIC and DRASTICAI maps shows an important contribution of the anthropogenic influence (Fig. 5). It is possible to mention all over the surveyed area, but specifically in Idanha-a-Nova municipality, a rousing effect from low/moderate vulnerability up to highly vulnerable. 
Fig. 3 DRASTIC and DRASTICAI layer attributes
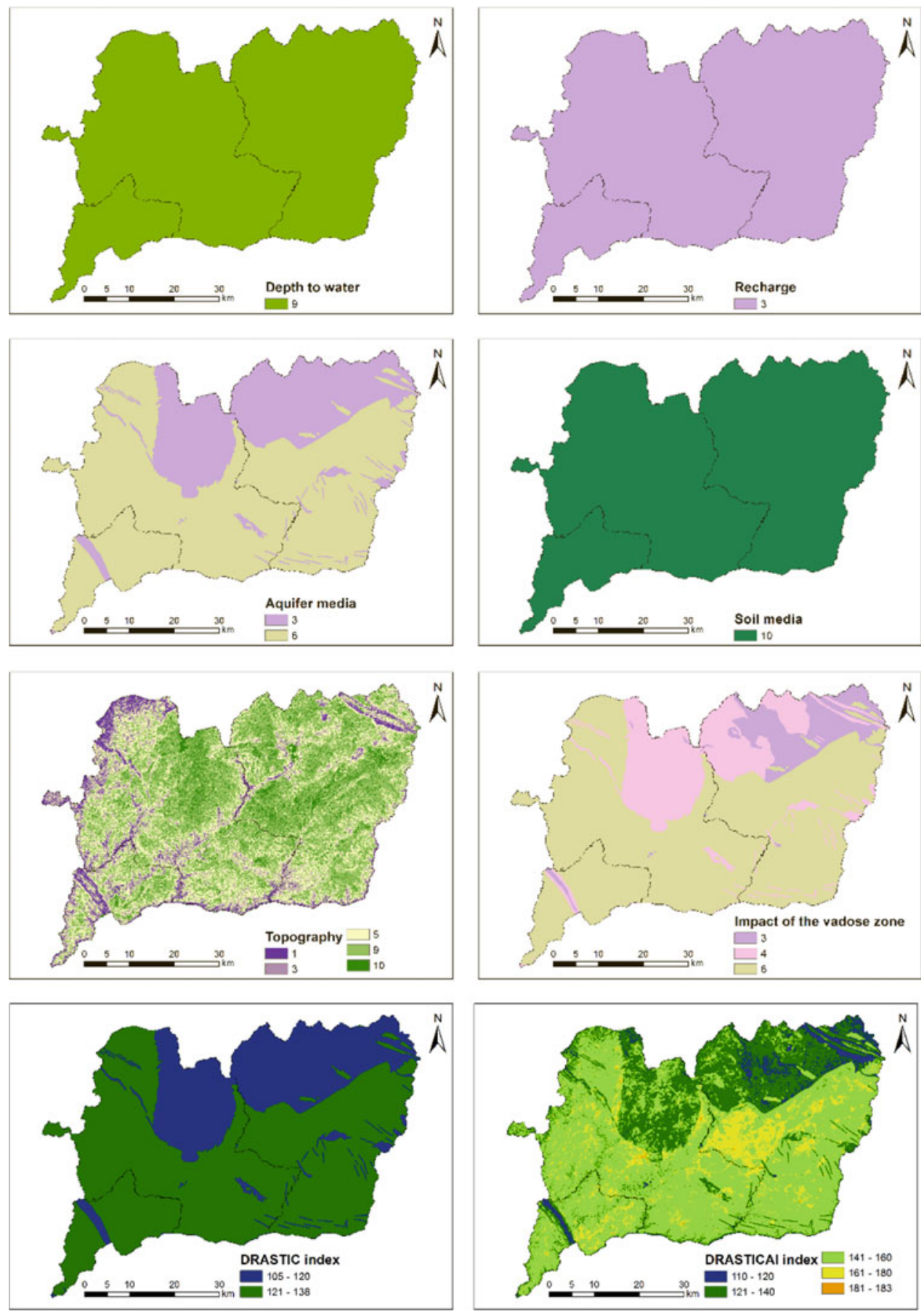
Fig. 4 DRASTIC (a) and DRASTICAI (b) maps

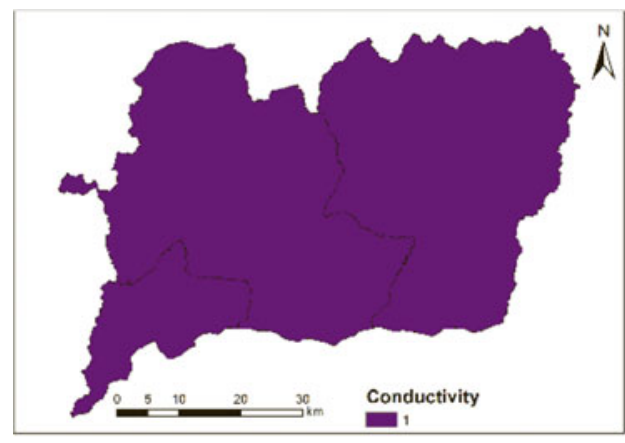

(a)

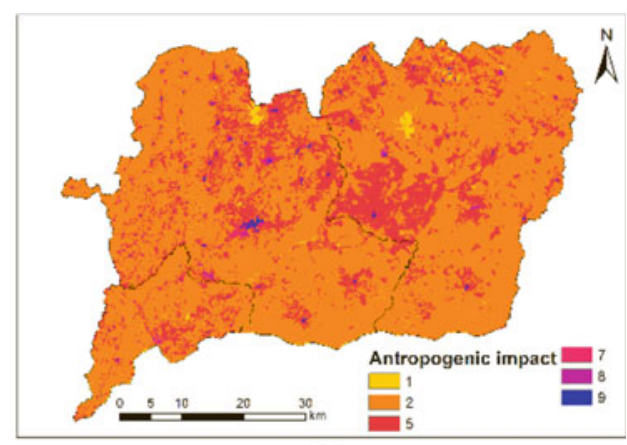

(b)

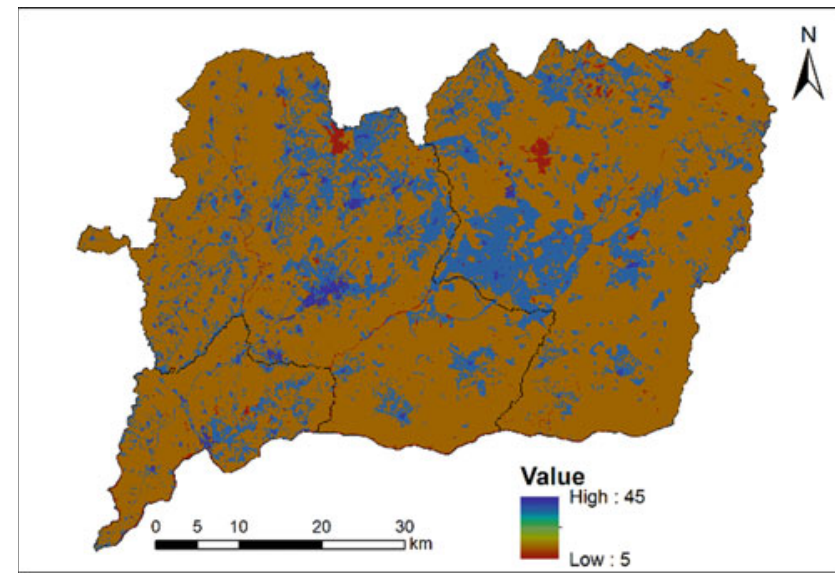

Fig. 5 Map representing the algebraic subtraction of DRASTIC and DRASTICAI

\section{Concluding Remarks}

This survey aimed at the evaluation of the groundwater vulnerability to contamination, in the Naturtejo Geopark area, using a modified DRASTIC index, DRASTICAI. This new index was constructed by adding a new attribute designated as anthropogenic influence.

The DRASTICAI spatial patterns indicate a clear influence of anthropogenic activities, mainly in the Idanhaa-Nova municipality.

Water is one of the most strategic resources in the world. Portugal has important resources of groundwater that may be strategic to face the expected dry years to come. Furthermore, regularly monitoring and evaluating groundwater quality is needed for integrated management and policymaking.

\section{References}

Albuquerque MTD, Lobón GS, Oliveira SF, Martínez-Alegría R, Antunes IMH (2013) Spatio-temporal groundwater vulnerability assessment: a coupled remote sensing and GIS approach for historical land cover reconstruction. Wat Res Manag 27(13):45094526

Aller L, Bennet T, Lehr JH, Petty RJ (1987) DRASTIC: a standardized system for evaluating groundwater contamination potential using hydrogeologic settings. J Geol Soc India 29:23-37

Awawdeh M, Obeidat M, Zaiter G (2014) Groundwater vulnerability assessment in the vicinity of Ramtha wastewater treatment plant, North Jordan. Appl Wat Sci 5:321-334

Babiker I, Mohammed M, Hiyama T, Kato K (2005) A GIS-based DRASTIC model for assessing aquifer vulnerability in Kakmigahara heights, Gifu Prefecture, central Japan. Sci Total Environ 345:127-140

Singh A, Srivastav SK, Kumar S, Chakrapani GJ (2015) A modified-DRASTIC model (DRASTICA) for assessment of groundwater vulnerability to pollution in an urbanized environment in Lucknow, India. Environ Earth Sci 74:5475-5490

Stigter T, Almeida P, Carvalho D, Ribeiro L (2006) Evaluation of an intrinsic and a specific vulnerability assessment method in comparison on a regional scale. Hydrogeol J 14(3):79-99A

Shirazi SM, Imran HM, Akib S, Yusop Z, Harun ZB (2013) Groundwater vulnerability assessment in the Melaka State of Malaysia using DRASTIC and GIS techniques. Environ Earth Sci 70:2293-2304 